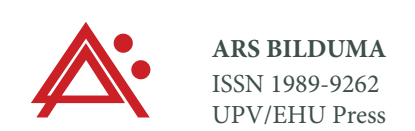

ARSBILDUMA (CC BY-NC-ND 4.0)

https://doi.org/10.1387/ars-bilduma.20919 BIBLID [(2020), 10; 91-107]

Recibido: 06/06/2019 Aceptado: 30/09/2019

\title{
EL CATÁLOGO MONUMENTAL Y ARTÍSTICO DE LA PROVINCIA DE NAVARRA DE 1916: CRÓNICA DE UNA OPORTUNIDAD PERDIDA
}

\author{
THE MONUMENTAL AND ARTISTIC CATALOGUE OF THE PROVINCE OF NAVARRE \\ OF 1916: CHRONICLE OF A LOST OPPORTUNITY
} LE CATALOGUE MONUMENTAL ET ARTISTIQUE DE LA PROVINCE DE NAVARRE
DE 1916 : CRÉTION D'UNE OCCASION MANQUÉE

RESUMEN

\section{PILAR ANDUEZA UNANUA}

Universidad de La Rioja

Departamento de Ciencias Humanas C/ Luis de Ulloa 2

26004 Logroño (La Rioja)

m-del-pilar.andueza@unirioja.es

https://orcid.org/0000-0001-5844-5609
Siguiendo sendos reales decretos de 1900 y 1902 que ordenaban recoger "todas las riquezas monumentales y artísticas" de la nación, en 1916 se encargó al escritor y periodista Cristóbal de Castro la ejecución del catálogo correspondiente a la provincia de Navarra. El presente artículo estudia la gestación y desarrollo de dicho catálogo, así como la metodología y bibliografía empleadas. Ofrece también su descripción física y examina y valora el material fotográfico y textual de sus cinco volúmenes, poniendo de manifiesto el carácter fragmentario e incompleto de la obra, así como sus abundantes errores, imprecisiones y nulas aportaciones.

PALABRAS CLAVE

Catálogo monumental; inventario; patrimonio; monumento; Navarra, Cristóbal de Castro.

\section{ABSTRACT}

Following the royal decrees of 1900 and 1902 which ordered the collection of "all the monumental and artistic heritage" of the nation, in 1916 the writer and journalist Cristóbal de Castro was commissioned to carry out the catalogue corresponding to the province of Navarre. This article studies the genesis and development of this catalogue, as well as the methodology and bibliography used. It also offers its physical description and examines and assesses the photographic and written material of its five volumes, revealing the fragmentary and incomplete nature of the work, as well as its many errors, inaccuracies and nonexistent contributions.

\section{KEYWORDS}

Monumental catalogue; inventory; heritage; monument; Navarra, Cristóbal de Castro.

\section{RÉSUMÉ}

Suite à deux décrets royaux de 1900 et 1902 qui ordonnaient de rassembler "toute la richesse monumentale et artistique" du pays, l'écrivain et journaliste Christophe de Castro fut chargé de l'exécution du catalogue correspondant à la province de Navarre en 1916. Le présent article étudie la gestation et le développement de ce catalogue, ainsi que la méthodologie et la bibliographie utilisées. Il offre également sa description physique, examine et évalue le matériel photographique et l'ensemble des textes de ses cinq volumes, en soulignant la nature fragmentaire et incomplète de l’ouvre, ainsi que ses nombreuses erreurs, inexactitudes et contributions inutiles.

\section{MOTS-CLÉS}

Catalogue monumentale; inventaire; patrimoine; monument; Navarra, Cristóbal de Castro. 


\section{INTRODUCCIÓN}

Asumidas las competencias de tutela del patrimonio por el Estado liberal, la desamortización de los bienes eclesiásticos iniciada de manera definitiva en España en 1835 hizo imprescindible el registro e identificación de los mismos a través de inventarios y catálogos. Se pretendía de este modo neutralizar su destrucción, venta y expolio. Aunque las reales órdenes de 29 de junio de 1835, de 3 de mayo de 1840 y de 2 de abril de 1844 trataron de formar una relación de bienes muebles procedentes de conventos suprimidos, de templos que contuvieran sepulcros de reyes y personajes célebres, así como de inmuebles de mérito artístico respectivamente, no fue hasta la creación de las Comisiones de Monumentos Artísticos e Históricos el 13 de junio de 1844 cuando se pretendió dar un impulso definitivo a aquellas tareas. Para ello, se encomendó a estos nuevos organismos, entre otras funciones, "adquirir noticia de todos los edificios, monumentos y antigüedades que existan en su respectiva provincia y que merezcan conservarse" y "formar catálogos, descripciones y dibujos de los monumentos y antigüedades que no sean susceptibles de traslación, ó que deban quedar donde existen, y también de las preciosidades artísticas que por hallarse en edificios que convenga enagenar, ó que no puedan conservarse merezcan ser trasmitidas en esta forma á la posteridad"1. A lo largo de toda la segunda mitad de la centuria se sucedieron diversas tentativas para cumplir este mandato, pero la falta de recursos económicos, técnicos y humanos impidió desarrollar aquella empresa con éxito ${ }^{2}$.

Tras estos fallidos intentos de catalogación sistemática del patrimonio histórico-artístico español, un real decreto fechado el 1 de junio de 1900 ordenó la elaboración del Catálogo artístico y monumental de la Nación que, aspirando a obtener un registro sistemático y completo "de todas las riquezas monumentales y artísticas existentes", sería realizado provincia a provincia y financiado por el Ministerio de Instrucción Pública y Bellas Artes ${ }^{3}$.

Real Orden de 13 de junio de 1844 por la que se crean las Comisión de Monumentos artísticos e históricos, art. 3.1 y 3.6 (Gaceta de Madrid, n. ${ }^{\circ} 3568$, p. 1, 21-VI-1844).

2 A este respecto puede verse: GONZÁLEZ-VARAS, I.: Conservación de Bienes Culturales. Teoría, histo ria, principios y normas. $4^{\mathrm{a}}$ ed., Madrid, Cátedra, 2005, pp. 79-80. MUÑOZ COSME, A.: "Catálogos e inventarios del Patrimonio en España”, en LOPEZ-YARTO ELIZALDE, A. y OTROS: El Catálogo Monumental de España (1900-1961). Investigación, restauración y difusión. Madrid, Ministerio de Cultura 2012 p. 25. Sobre los diversos intentos de catalogación realizados en Navarra desde su Comisión de Monumentos puede consultarse: QUINTANILLA MARTÍNEZ, E.: La Comision de monum ricos y artísticos de Navarra. Pamplona, Gobierno de Navarna,

Real Decreto de 1 de junio de 1900 para la formación del Catálogo monumental y artístico de la Nación (Gaceta de Madrid, n. ${ }^{\circ} 153$, p. 1079, 2-VI-1900)
De manera paralela, una real orden con la misma fecha nombraba para su elaboración al historiador del arte Manuel Gómez Moreno, que debería iniciar la tarea por Ávila y recibiría como pago 800 pesetas mensuales durante los ocho meses que se estipularon como plazo ${ }^{4}$. Sin embargo, pronto se vio la imposibilidad de que una única persona pudiera catalogar todo el patrimonio del país, por lo que el Real Decreto de 14 de febrero de 1902, insistiendo en la importancia de la empresa, abría la labor a otros autores que serían nombrados por una comisión mixta compuesta por miembros de las Reales Academias de la Historia y de Bellas Artes, bajo la dirección del Ministerio ${ }^{5}$. Sin embargo, la preparación poco adecuada de algunos de ellos, la falta de unidad en los objetivos y métodos, los procedimientos poco operativos, así como su dilación en el tiempo desembocaron en la pérdida de rigor del proyecto y en resultados desequilibrados, e incluso en partes inacabadas, habiéndose realizado finalmente treinta y nueve de las cuarenta y siete provincias . Es en este contexto donde hallamos el Catálogo Monumental y Artístico de la provincia de Navarra, desarrollado entre 1916 y 1917 por Cristóbal de Castro $^{7}$.

4 Real Orden de 1 de junio de 1900 nombrando a Manuel Gómez Moreno para la formación del Catálogo monumental y artístico de la Nación (Gaceta de Madrid, n. ${ }^{1} 153$, p. 1081, 2-VI-1900).

5 Real Decreto de 14 de febrero de 1902 para la continuación del Inventario general de los Monumentos históricos y artísticos del Reino (Gaceta de Madrid, n. ${ }^{\circ} 49$, pp. 734-735, 18-II-1902).

6 Estudios pormenorizados sobre el Catálogo Monumental de España, su contexto y significación pueden verse en: HERNÁNDEZ NÚÑEZ, J. C.: "Reflexiones sobre el Catálogo Monumental de España" PH. Boletín del Instituto Andaluz del Patrimonio Histórico, 15, 1996, pp. 162-166; LÓPEZ-YARTO ELIZALDE, A.: El Catálogo Monumental de España (1900-1961). Madrid, CSIC, 2010; LÓPEZ-YARTO ELIZALDE, A. y OTROS: El Catálogo Monumental de España (1900-1961). Investigación, restauración y difusión Madrid, Ministerio de Educación, 2012. Sobre la evolución de catálogos e inventarios en Españon Más de lon Españ, ad COSME, A.: op. cit., pp. 14-37. SAURET GUERRERO, T.: "Los catálogos monumentales. La puesta en valor de los Bienes Patrimoniales por el conocimiento y la información especializada", PH. Boletín del Instituto Andaluz del Patrimonio Histórico, 32, 2000, pp. 61-65. GARCÍA GAINZA, M. C.: "Inventarios y catálogos. Un siglo en la documentación y el conocimiento del Patrimonio Cultural (1907-2007)”, en GONZÁLEZ GÓMEZ, J. M. y MEJÍAS ÁLVAREZ, M. J. (coords.): Estudios de Historia del Arte: centenario del Laboratorio de Arte (1907-2007). Vol. 1, Universidad de Sevilla, 2009, pp. 181-198.

7 CASTRO C de. Catálogo Monumental y Artístico de la provincio de Navarra redactado conforme a ha

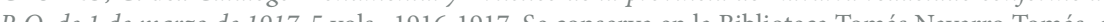
CSIC (Madid). Signturas: RESC/1197-RESC 1201. Como los correspondientes a otas provinct están digitalizados y pueden verse a través de: http://biblioteca.cchs.csic.es/digitalizacion_tnt/ (consultado el 11/03/2019) 


\section{CRISTÓBAL DE CASTRO}

Hijo de Juan de Castro y Orgaz y Francisca de Paula Gutiérrez del Castillo, Cristóbal de Castro nació en Iznájar (Córdoba) el 22 de noviembre de 1874 en el seno de una familia numerosa, donde tanto su progenitor como varios de sus hermanos fueron escritores. Cursó Derecho en la Universidad de Granada y en la Universidad Central de Madrid, si bien no terminó sus estudios. Su vida transcurrió en la capital, dedicado al periodismo y a la literatura, donde cultivó la poesía, el teatro, la novela corta, el drama y el ensayo, desarrollando a menudo temas costumbristas de cuño andaluz y femeninos. A su pluma correspondieron también traducciones al español de autores como Gorki, Gógol, Tolstoi, Andreief, Steimberg, Turguieniev, Botchareva, Lunst, Wilde, Molière, Ibsen, Pirandello, Goethe o Goldoni, junto con adaptaciones de comedias clásicas españolas. Fue académico de la Real Academia de Ciencias, Bellas Letras y Nobles Artes de Córdoba y de la Academia Hispanoamericana de Cádiz ${ }^{8}$.

Sus trabajos en relación con la catalogación del patrimonio español arrancaron el 1 de febrero de 1912, cuando se le adjudicó la realización del catálogo de la provincia de Araba/ Álava, al que seguirían los correspondientes a Orense (1914-1915), Logroño (1915-1916), Navarra (1916-1917), Santander (1918), Cuenca (h. 1920-1921) y Canarias (1921-1922). Aunque también fue elegido para realizar el correspondiente a Bizkaia en 1913, la Comisión de Monumentos de aquella provincia se opuso, asumiendo ella el encargo al que ni siquiera dio inicio ${ }^{10}$.

A la vista del trabajo presentado, no cabe duda de que Castro carecía de la formación adecuada para llevar a cabo aquella labor científica que requería conocimiento y método. Tampoco lo ocultaba, tal y como comprobamos en la prórroga que solicitó para ejecutar

8 CRUZ CASADO, A.: "Cristóbal de Castro Gutiérrez", en Diccionario biográfico de la Real Academia de la Historia, http://dbe.rah.es/biografias/11626/cristobal-de-castro-gutierrez (consultado el 11/03/2019).

9 LÓPEZ-YARTO ELIZALDE, A.: op. cit., pp. 43-45, 49-50, 54-55, 59-60. LÓPEZ-YARTO ELIZALDE A.: "Los autores del Catálogo Monumental de España", en LÓPEZ-YARTO ELIZALDE, A. y OTROS: op. cit., p. 42. MARTÍNEZ CANO, J.: "Fotografías en el Catálogo Monumental de Cuenca", en VILLENA

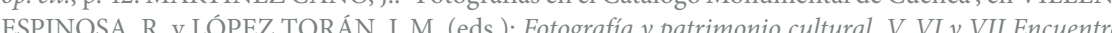
ESPIN

10 DÍEZ PATON, E.: "La Junta de Cultura Vasca y la redacción de un Catálogo Monumental para Bizkaia (1717-1936), Ars Bilduma, 9, 2019, p. 139. https://www.ehu.eus/ojs/index.php/ars_bilduma/issue/ view/1757 (consultado el 15/10/2019). el catálogo alavés, donde señalaba que desarrollaba aquella tarea "procurando realizar, cuando no con la ciencia, que le falta, con la diligente escrupulosidad que ha probado en diversas obras..."11.

López-Yarto, que estudió todos los autores del catálogo español, señaló que Castro era el autor "más inepto" de cuantos participaron en aquel vasto proyecto ${ }^{12}$. Cuando en 1915 se publicó el catálogo de Araba/Álava, único editado, se desató un escándalo que llegó incluso a las Cortes, pues, ante la pobreza de los resultados del estudio, algunas voces consideraron que se estaba despilfarrando el dinero público. No faltaron tampoco las críticas entre expertos en patrimonio. Así, tal y como han recopilado Hernández Núñez y López-Yarto, el académico Elías Tormo denunció ya entonces su improvisación, sus deficiencias, la ausencia de un vocabulario científico, la confusión con los estilos...: el "no uso de las palabras técnicas y el no interrogarse ante los problemas elementales de la construcción". Varias décadas después, todavía Gaya Nuño se referiría a Castro como periodista de "profundísima ignorancia [...], no hay palabras para condenar la osadía de ese hombre, que no sabía nada de nada, que comentaba todo con la postura del que se halla ante un enigma"13. Ante esta situación cabe preguntarse por qué la comisión mixta aprobó sus peticiones para realizar nuevos catálogos. Creemos que la respuesta se halla en sus relaciones personales que habrían facilitado su trayectoria profesional. De hecho, en 1919 Leopoldo Torres Balbás, además de criticar la orientación y el concepto del catálogo, afirmaba que había autores "periodistas y amigos de políticos desconocedores en absoluto de nuestro arte antiguo, a los que se les concedió el favor oficial con la complicidad de una Comisión que piadosamente deseamos creer incompetente"14. En nuestra opinión, Castro debió de ser uno de ellos y aquí radicaría la clave, resultando determinante su amistad con su paisano Julio Burell y Cuéllar, ministro de Instrucción Pública y Bellas Artes en 19101911, así como en 1915-1917 y, finalmente, en $1918^{15}$. Su presencia en el gobierno del conde

1 LÓPEZ-YARTO ELIZALDE, A.: op. cit., p. 43.

12 Ibid., p. 17.

13 HERNÁNDEZ NÚÑEZ, J. C.: op. cit., p. 164. LÓPEZ-YARTO ELIZALDE, A.: op. cit., p. 45

14 ISAC MARTÍNEZ DE CARVAJAL, A.: "La ponencia de D. Leopoldo Torres Balbás en el VIII Congreso Nacional de Arquitectos de 1919”, Cuadernos de arte de la Universidad de Granada, 20, 1989, pp. 195-212.

15 Real Decreto de 9 de junio nombrando ministro de Instrucción Pública y Bellas Artes a Julio Burell y Cuéllar (Gaceto de Madrid n.o 161, p. 530,10-VI-1910). Real Decreto de 9 de diciembre nombrando Cuent (G Ceta de Madrid n.o ministro de instruccion Publica Bellas Artes a shio Bureny Cueclar (Goceta de Madrid, n. 544, p. 643, 10-XIr-1915). Real Decreto de de novienbre nombranco ministro de Instrucción Pública y Bellas Artes a Julio Burell y Cuéllar (Gaceta de Madrid, 314 p. 573, 10-XI-1918). URQUIJO Y GOITIA, J. R. de: Gobiernos y ministros españoles en la Edad Contemporánea. Madrid, CSIC, 2001, pp. 92, 95 y 173. 
de Romanones (1915-1917) coincide plenamente con las fechas de encargo y ejecución del catálogo de Navarra que ahora nos ocupa. Tampoco podemos perder de vista que era amigo del también cordobés Alcalá Zamora, presente como ministro de Fomento en el gobierno de Manuel García Prieto en 1917-1918, lo que ratifica su cercanía a los círculos gubernativos y por tanto a los órganos de decisión ${ }^{16}$.

\section{GESTACIÓN Y DESARROLLO}

Tras haber redactado los catálogos de las provincias de Araba/Álava, Orense y Logroño, el 21 de febrero de 1916 Cristóbal de Castro solicitó a la comisión mixta la realización del catálogo de una nueva provincia. Recibió como respuesta el encargo de ejecutar el correspondiente a Navarra, proyecto que había sido demandado sin éxito por Antonio Vives el 8 de julio de 1909, tras haber entregado el de Baleares ${ }^{17}$.

El 1 de marzo de 1916 una real orden encargaba a Castro formalmente la catalogación de "todos los Monumentos históricos y artísticos, así como los objetos de reconocido mérito que existan en la provincia de Navarra”, otorgándole ocho meses de plazo y un pago de 800 pesetas mensuales con cargo al capítulo 13 , artículo $3^{\circ}$, concepto $4^{\circ}$ del presupuesto vigente en el Ministerio. Se instaba a las corporaciones y autoridades a cooperar con el investigador en todo aquello que necesitara para llevar a cabo el cometido. El director general de Bellas Artes fue el encargado de remitir la real orden al presidente de la Comisión Provincial de Monumentos de Navarra ${ }^{18}$. Fue en la sesión de 30 de marzo de aquel año cuando la mencionada comisión navarra quedó informada del "encargo dado a D. Cristóbal de Castro, de la catalogación de los Museos provinciales", expresión recogida en sus actas que no respondía con exactitud al proyecto comunicado ${ }^{19}$

16 Sobre estas amistades: CRUZ CASADO, A.: op. cit

17 LÓPEZ-YARTO ELIZALDE, A.: op. cit., p. 55

18 Archivo Real y General de Navarra (en adelante AGN), Comisión de Monumentos históricos y artísticos de Navarra (en adelante CMHAN), caja 9, 1916, carpeta 3: comunicación del Director General de Bellas Artes at Presidente de bomicto Bellas Artes a Presidente de orden para la ejecución del Catálogo montmental y artistico de la provincia de Navarra.

9 AGN, CMHAN, caja 17: Actas de la comisión, t. III, s. f (30-III-1916). Boletín de la Comisión de Monumentos históricos y artísticos de Navarra. Segunda época, año 1916, tomo $7^{\circ}$, n. ${ }^{\circ} 25$, enero, 1916, p. 4 Estuvieron presentes Florencio Ansoleaga, Manuel Ruiz de la Torre y Carlos de Marichalar, habiendo
Desde el mes de abril de 1916, Castro fue haciendo entregas mensuales del trabajo sobre las que la comisión mixta emitía su correspondiente informe, preceptivo para poder cobrar los honorarios ${ }^{20}$. Una real orden de 6 de enero de 1917, previa solicitud del autor, le concedió una prórroga de cuatro meses, prórroga que, de nuevo a sus instancias, fue ampliada hasta el final de año en otra real orden fechada en 28 de febrero de 1917. Se le otorgó así como plazo final el mes de diciembre de 1917, fecha en que efectivamente se constata la última entrega. Ciertamente resulta extraño que en un margen de escasas semanas Castro solicitara dos moratorias. Sin duda, era un trabajo muy bien remunerado, lo que desde luego pudo influir en tratar de alargar el contrato. Sin embargo, lo que adujo para su segunda petición se fundamentó "en ser Navarra una de las provincias más ricas monumental e históricamente". Y así, "considerando que en la provincia de Navarra se da la circunstancia excepcional de haber constituido uno de nuestros reinos históricos lo que hace más copioso su tesoro artístico y monumental", junto con la necesidad de hacer "comprobaciones detalladas y repetidas que entrarían gran consumo de tiempo" y "por lo accidentado del territorio de la región", el monarca concedió esta segunda prórroga, previo informe favorable de la comisión mixta que se apoyó para ello en los plazos dados al conde de Cedillo para la provincia de Toledo años atrás ${ }^{21}$.

Entregado finalmente el trabajo de Navarra, el informe global de la comisión, fechado el 13 de marzo de 1918, lo consideró "labor completa y lo más metódica posible [...] catalogación minuciosa y esmerada. Se ha informado y documentado debidamente [...]. Representa un avance sobre cuanto de tal región no era conocido, esclareciendo a su vez problemas que antes parecían de difícil solución y que gracias a sus propias observaciones quedan hoy dilucidadas"22. Desconocemos quién fue el autor de este juicio que, desde luego, como analizaremos posteriormente, no respondía a la realidad, pues el trabajo entregado carecía de método y ofrecía significativos errores, lagunas y nulas novedades.

Son escasas las noticias relativas a la presencia de Castro en Navarra, a los recorridos que siguió, las visitas que realizó y al ritmo de trabajo que desarrolló. Según podemos leer tanto en El Pensamiento Navarro como en el Diario de Navarra, el escritor llegó a

excusado su asistencia Arturo Campión y Eduardo Carceller.

20 LÓPEZ-YARTO ELIZALDE, A.: op. cit., p. 55.

21 AGN, CMHAN, caja 10, 1917, carpeta 28: Real Orden con las prórrogas concedidas a Castro que remite el Director General de Bellas Artes al Presidente de la Comisión provincial de Monumentos de Navarra. 22 LÓPEZ-YARTO ELIZALDE, A.: op. cit., p. 55. 
Pamplona desde Madrid en los días previos al 18 de agosto de 1916. Y así, ambos rotativos recogiendo una nota común, narraban que venía acompañado "del redactor artístico señor España..., comisionados por el Ministerio de Instrucción Pública para preparar la edición del Catálogo Monumental de Navarra artística. La obra será de divulgación y servirá de grandísimo auxiliar a las propagandas del turismo". Mientras el periódico tradicionalista les daba la bienvenida y abogaba por "apoyar con las facilidades morales de estos casos la publicación de obra tan interesante porque al fin ha de redundar en beneficio del país", el noticiero liberal informó de que el día 18 Castro y su fotógrafo habían visitado al gobernador civil, Ricardo de la Rosa, a la sazón presidente de la Comisión de Monumentos de Navarra "para darle a conocer la misión que aquí los trae, recibiendo ellos de dicha autoridad toda clase de facilidades para la ejecución de la obra que van a desarrollar"23. Esta actitud del gobernador de Navarra contrasta con la que Castro relató sobre su homónimo en Logroño, Laureano Irazazábal, quien "sin prestar mientes ni cortesía a las cartas de presentación que para él llevamos, ni a sus deberes oficiales como Presidente de la Comisión provincial de Monumentos, recibionos tan distraídamente que nos obligó a cortar la entrevista, en una de las salas de juego del Casino, donde se dignó citarnos"24.

Aquella misma tarde del día 18 Castro y su fotógrafo salieron ya a recorrer la provincia, si bien desconocemos cuánto tiempo les llevó hacerlo y las rutas que siguieron, datos que ofrece de manera más pormenorizada en los catálogos de Santander, Orense y Cuenca. El cordobés alabó en la introducción de su obra navarra "la incomparable red de comunicaciones que tanta fama han conquistado a Navarra", incluyendo carreteras, por las que llegó a Roncesvalles, Baztan, Roncal, Puente la Reina y Estella, los ferrocarriles que usó para trasladarse a Tafalla y Tudela y el tranvía eléctrico del Irati que le llevó por Aoiz hasta Sangüesa, siendo los únicos datos que tenemos sobre su periplo navarro. A la vista de los resultados, podemos afirmar que Castro no visitó toda la provincia, ni todas las localidades recogidas en el catálogo, sino que puntualmente se dirigió a determinados lugares, posiblemente siguiendo las indicaciones de algunos eruditos locales.

23 El Pensamiento Navarro, 18-VIII-1916, p. 1. Diario de Navarra, 19-VIII-1916, p. 1

24 CASTRO, C. de: Catálogo Monumental y Artístico de la Provincia de Logroño, 1916, t. I, texto, fol. 12

\section{METODOLOGÍA Y BIBLIOGRAFÍA}

Poco sabemos de la metodología empleada por Castro para desarrollar el catálogo de Navarra más allá de recorrer la provincia "escrupulosamente, visitando sus monumentos y archivos, tomando apuntes y fotografías y procurando recoger viejos latidos de la Arqueología y de la Historia”25, afirmación sin duda exagerada porque creemos que no recorrió toda la geografía navarra, ni investigó en archivo alguno y el manejo de bibliografía fue muy limitado.

Aunque las actas de la Comisión de Monumentos de Navarra no ofrecen noticias sobre la realización del catálogo, más allá de la notificación de su ejecución, no cabe duda de que varios de sus miembros facilitaron extraordinariamente el trabajo a Castro. Así se desprende no solo del texto, de la bibliografía utilizada y de muchas de las fotografías publicadas, sino también de las palabras de agradecimiento que el propio autor mostró en la introducción de la obra, donde habla "del saber amable, la hospitalidad afectuosa, y los vastos y sólidos conocimientos de personas tan competentes en Arqueología, en Historia y en cuanto antigua y modernamente se relaciona con Navarra, como los señores Don Julio Altadill, Don Mariano Arigita, Don Arturo Campión y Don Lorenzo (sic) Ansoleaga”, miembros todos de la mencionada comisión ${ }^{26}$. Su gratitud se extendió también hacia Eustaquio Echave Susaeta, director de El Pensamiento Navarro, Jesús Etayo, oficial del Archivo de Navarra, y el periodista Julio Martínez, por su apoyo y aportaciones en la empresa ${ }^{27}$.

Castro recogió pormenorizadamente en la introducción buena parte de la bibliografía teóricamente utilizada, hasta alcanzar veintisiete obras, fundamentalmente de geografía, historia y documentación, pertenecientes a autores como Moret, Yanguas, Goyeneche,

25 CASTRO, C. de.: Catálogo Monumental y Artístico de la Provincia de Navarra..., op. cit., t. I. texto, fol. 2 26 De ellos emplearía el tomo correspondiente a Navarra de la Geografía General del País Vasco-Navarro dirigido y escrito por Altadill, y en el que también colaboraron Fermín Marquina, fray Eusebio de Echalar, Arturo Campión y Mariano Arigita. De este último utilizó asimismo la Colección de documentos inéditos para la historia de Navarra, Los judíos en el País Vasco y La Asunción de la Santísima Virgen y su culto en Navarra: excursión histórica, mientras que también se sirvió de la obra sobre los dólmenes de Aralar que Ansoleaga escribió en compañía de Aranzadi (CASTRO, C. de.: Catálogo Monumental y Artístico de la Provincia de Navarra..., op. cit., t. I, texto, fol. 2).

27 Echave Etayo y Martínez le ofrecieron "copioso caudal de documentos y fotografías" y, junto con Altadill, "rivalizando en amable gentileza", lo visitaron en su hotel, dándole facilidades para el cometido que pretendía. También acudieron a cumplimentarlo en su hospedaje el gobernador, el alcalde y Arigita, a la sazón arcediano de la catedral de Pamplona (CASTRO, C. de.: Catálogo Monumental y Artístico de la 
Argamasilla de la Cerda, Vargas Ponce, Zamacola, Nadal y Gurrea, Olóriz, Nombela Madrazo, Iribarren, Sáinz y P. de Laborda, e Iturralde ${ }^{28}$. A sus títulos se unieron cuatro en francés y uno en inglés ligados a la historia y etnografía de la Baja Navarra y del País Vasco ${ }^{29}$, así como tres publicaciones periódicas: Boletín de la Comisión de Monumentos Históricos y Artísticos de Navarra, Revista Euskara y La Avalancha ${ }^{30}$. Puntualmente en el desarrollo del catálogo iría uniendo obras más específicas ligadas a monumentos concretos.

No fue el de Navarra el único catálogo en el que Castro citó las obras consultadas. Lo hizo también en los catálogos previos de Araba/Álava, Logroño y Orense, donde refirió pormenorizadamente más de veinticinco, treinta y cincuenta títulos respectivamente, y lo hizo también posteriormente en el de Cuenca, aunque en este caso se centró más en la relación de autores. En contraste, en el catálogo de Santander no hizo mención alguna a fuentes documentales y bibliográficas. En cualquier caso, consideró que Navarra contaba con "abundante bibliografía" que, según él, contenía "centenares de libros y millares de documentos ya catalogados", suficientes "para abrumar por su cantidad y calidad, no ya nuestra modesta condición, si no (sic) la de ingenios doctísimos"31, palabras con las que

Provincia de Navarra..., op. cit., t. I, texto, fols. 3 y 124).

28 Se trataba de los Anales del Reino de Navarra y las Investigaciones históricas de las antigüedades del Reyno de Navarra, de José de Moret, Diccionario de antigüedades del Reino de Navarra, de José Yanguas y Miranda, Diccionario geográfico-histórico de España de la Real Academia de la Historia, Executoria de nobleza, antigüedad y blasones del Valle de Baztán, de Juan de Goyeneche, Nobiliario y armería genera de Nabarra, de Joaquín Argamasilla de la Cerda y Bayona, Historia de las naciones vascas, de Juan Antonio Zamacola (aunque dio como autor J. A. Amezola), Glorias navarras: historia compendiosa del origen del antiguo Reino de Navarra, de José Nadal de Gurrea, El Romancero de Navarra, de Hermilio Olóriz Crónica de la provincia de Navarra, de Julio Nombela, Navarra y Logroño, de Pedro de Madrazo, Apuntes sobre la historia antigua de Estella de Sebastián Iribarren, Apuntes tudelanos, de Mariano Sainz y de Laborda (erróneamente lo denominó Sainz Pérez de la Buda) y La Prehistoria de Naras de Jun de Labora (erróneano jua Iturralde y Suit. Se unia finalmente un manuscrito de Jose de Vargas Ponce que figura como Extract del índice del Archivo de Comptos (CASTRO, C. de.: Catálogo Monumental y Artístico de la Provincia de Navarra..., op. cit., t. I, texto, fols. 6-8).

29 Las monografías extranjeras, de las que aportamos su primera edición, eran: Les basques et le Pays Basque, moeurs, language et histoire (1882) y Le folk-lore du Pays Basque (1883), ambas de Julien Vinson, Voyage en Navarre pendant l'insurrection des basques (1830-1835), de J. Agustin Chaho (1836), La Navarre française, de Gustave Bascle de Lagrèze (1881-1882), Les anciens dieux des Pyrénées, de Julien Sacaze (1885), La Sorcellerie en Béarn et dons le pays Basque, de Hilarion Bathety Ribaut (1879), y

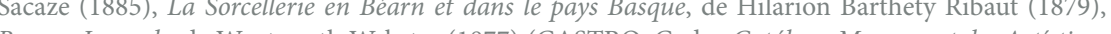
la Provincia de Navarra..., op. cit., t. I, texto, fol. 7).

30 CASTRO, C. de.: Catálogo Monumental y Artístico de la Provincia de Navarra..., op. cit., t. I, texto, fols. 6-7. 31 Ibid., fol. 5 parece querer disculpar o justificar una posible incapacidad para abordar y analizar todas las fuentes disponibles. En cualquier caso, como veremos posteriormente, su trabajo se alimentó básicamente de las obras de Madrazo, Campión, Altadill e Iturralde.

\section{DESCRIPCIÓN FÍSICA: TOMOS, ENCUADERNACIÓN Y FOLIOS}

Finalizado el trabajo, Cristóbal de Castro hizo entrega de cinco volúmenes con el Catálogo Monumental y Artístico de la provincia de Navarra, agrupándolos a su vez en dos tomos de texto y tres de fotografías. Si nos centramos en los siete catálogos realizados por Castro entre 1910 y 1921 y los sometemos a una comparación, podemos establecer algunas diferencias y analogías. Todos ellos constaban de un tomo con texto y uno de fotografías, exceptuando el de Orense que estaba dotado además de un segundo volumen con imágenes. Ante este panorama, el de Navarra resultó indiscutiblemente el más extenso de todos los redactados por Castro merced a sus dos volúmenes textuales y los tres ilustrados. No obstante, llama la atención el desfase existente entre el resultado final y la información que aporta el autor en la propia introducción, donde indicaba que, "como en anteriores catálogos", ofrecía un volumen de texto y otro de fotografías, "aun cuando por la abundancia de ambas cosas el "Catálogo de Navarra” ha de ser mucho más extenso, y por consiguiente de mucho más trabajo”32.

Los volúmenes correspondientes a Navarra, de $33 \mathrm{~cm}$, fueron presentados con una encuadernación en piel de tonalidad ocre con decoración gofrada, comolos correspondientes a Orense, Logroño, Santander y Cuenca, lo que contrasta con los entregados por otros autores que utilizaron para las cubiertas pieles de colores oscuros, piel vuelta, pergamino, tela, o a la holandesa ${ }^{33}$. En el caso navarro la cubierta alberga en un enmarque rectangular el título de la obra totalmente centrado: CATÁLOGO/MONUMENTAL Y ARTÍSTICO/ DE LA/ PROVINCIA DE NAVARRA. Debajo se añade información correspondiente al número de tomo y si se trata de fotografías o texto. Se completa con el nombre del autor en el ángulo inferior derecho y un emblema heráldico de la monarquía española ${ }^{34}$.

\section{Ibid., fol. 9.}

33 HIDALGO BRINQUIS, M.C.: "Interpretación material de los Catálogos Monumentales de España" y BENITO LOPE, R.: "Conservación y restauración de los originales del Catálogo Monumental de España", en LÓPEZ-YARTO ELIZALDE Y OTROS: op. cit., pp. 83-85 y 131-133 respectivamente.

34 Timbrado por corona real y orlado con el collar de la Orden del Toisón de Oro, sus cuarteles alternan 
No obstante, y a pesar de las similitudes en las portadas de todos los volúmenes navarros, se hace necesario distinguir dos modelos de encuadernación: el correspondiente a los tomos textuales responde a la tipología de libro e incorpora nuevamente en el lomo, en letra capital, los datos de autoría, título y número de tomo. Sin embargo, los que albergan las fotografías ofrecen un formato de carpeta. En su interior se alojan las hojas sueltas y puede cerrarse con mayor o menor presión a través de unas cintas de cuero situadas en el corte superior, inferior y delantero para impedir la pérdida del material.

Frente a estos tipos de encuadernación, Castro ofreció también otra modalidad para los catálogos de Santander y Cuenca. Se trataba de una sencilla carpeta formada por dos tapas duras independientes, forradas con el mismo tipo de piel, con cuatro perforaciones situadas cerca de los bordes largos, a través de los que se pasaban sendas cuerdas de cuero que recorrían las cubiertas internamente, y se abrochaban en el borde frontal. Su interior alojaba tanto texto como fotografías en hojas sueltas. Este sistema, que aportaba flexibilidad como ocurría con las carpetas empleadas para las imágenes en Navarra, se ideó especialmente ante la problemática generada por los volúmenes de fotografía ya que la diferencia de grosor existente entre la zona central de las hojas donde iban pegadas las ilustraciones y los lomos era sustancial, lo que dificultaba encuadernarlos correctamente, impidiendo una buena unión entre las tapas y el cuerpo del libro ${ }^{35}$.

Si la encuadernación de los dos tomos de texto es similar, en general podemos afirmar lo mismo para la presentación formal de su interior, donde Castro utilizó papel muy grueso en tono beige con un acabado mate y sin filigrana, similar al empleado para el catálogo de Santander ${ }^{36}$.

El primer tomo de texto está compuesto por 211 hojas escritas exclusivamente por el anverso a las que se suman otras dos hojas destinadas a la portada y el índice. Por su parte el segundo tomo ofrece 335 hojas con otras tres dedicadas al índice ${ }^{37}$. Ambas portadas, combinando tinta negra y roja, ofrecen de manera centrada el título con letras capitales: CATALOGO MONUMENTAL Y ARTISTICO/ DE LA/ PROVINCIA DE NAVARRA. En el

las armas de Castilla (primero y cuarto) y León (segundo y tercero), e incluyen una granada en punta y las flores de lis en el escusón. No hay alusión alguna a Navarra, ni a la Corona de Aragón.

35 HIDALGO BRINQUIS, M. C.: op. cit., p. 83.

36 Ibid., p. 85

37 En el tomo dos la primera hoja, que anuncia el Partido judicial de Pamplona, quedó sin numerar caso del primer volumen se completa además con un subtítulo: REDACTADO conforme á la/ R. O. De 1 de Marzo de 1917, por / Cristóbal de Castro, y se acompaña en ambos casos con un cuño del Archivo General de los Ministerios de Instrucción Pública y Bellas Artes y de Fomento. Por su parte el texto se ofrece mecanografiado en negro encerrado en un marco rojo, dejando un amplio margen. Sobre la parte superior se sitúa el número de folio.

Respecto al contenido, el primer tomo está dedicado a la historia de Navarra y al patrimonio monumental de la ciudad de Pamplona. Se articula por medio de una introducción, cinco capítulos, divididos a su vez en numerosos epígrafes, un apéndice con una relación de documentos de archivo, sellos medievales y piezas del Museo arqueológico, cerrándose con un índice ${ }^{38}$. Por su parte, el segundo tomo está dedicado a la catalogación del patrimonio histórico-artístico del resto de Navarra con su correspondiente índice final.

Esta presentación, con el mismo tipo de papel y el texto mecanografiado a una sola cara encerrado en un marco rojo, fue similar a la que utilizó para los catálogos de Logroño y Orense. Sin embargo, para Santander optó por una caja de escritura de mayor tamaño, enmarcada con línea negra discontinua, mientras para Cuenca eligió un papel-cartulina rojizo, escrito por ambas caras, en el que predominó casi absolutamente la tinta negra, tanto para los marcos como para los títulos.

En relación con la extensión y para establecer una comparación entre los tomos de texto de los distintos catálogos realizados por Castro, podemos afirmar que el de Logroño lo redactó a lo largo de 340 hojas con escritura por una sola cara y con un índice de cinco. No aportó índice en los trabajos de Orense (367 hojas), Santander (184 hojas) y Cuenca, donde empleó 108 folios por ambas caras.

En fecha indeterminada, a los dos tomos navarros de texto se les añadieron algunas correcciones, algún tachón y anotaciones manuscritas. En general, las rectificaciones están realizadas con lápiz, mientras los apuntes se ejecutaron con pluma. Las primeras, más abundantes en el primer tomo y escasas en el segundo, se destinaron fundamentalmente a enmendar algunos errores gramaticales y ortográficos, destacando especialmente aspectos ligados a la puntuación, erratas tipográficas, uso de mayúsculas y faltas ortográficas. Con otro ductus, más alargado e inclinado, y por tanto correspondiente a otra mano

38 Sendos olvidos o errores impiden conocer en el texto dónde arrancan los capítulos dos y cinco, por lo que hay que recurrir al índice para saberlo con exactitud. 
-posiblemente de Castro-, son abundantes las páginas que presentan anotaciones en ambos tomos. Varían desde una sola palabra a frases completas e incluso algún párrafo. Sirven para añadir monumentos o piezas olvidadas previamente ${ }^{39}$, completar alguna frase inconclusa ${ }^{40}$, agregar un título ${ }^{41}$, subsanar lo ya escrito ${ }^{42}$, aludir a alguna fotografía ${ }^{43}$, citar algún libro o plano, como ocurre en varias ocasiones con la figura de Lampére ${ }^{44}$, o referirse a otra parte del propio catálogo, generalmente para subsanar errores ${ }^{45}$.

En este sentido, si comparamos con los otros catálogos de Castro, resulta llamativo que apenas existen correcciones en los correspondientes a Logroño, Orense y Santander. Tampoco hay adiciones, excepto en el de Logroño, donde se añadió con la misma letra que el de Navarra la ubicación de las láminas a lo largo del texto, dinámica que no se repitió en ningún otro ejemplar y de manera muy puntual en el de Navarra. El catálogo de Cuenca ofrece algunas líneas manuscritas una vez borradas otras tantas líneas mecanografiadas, práctica que resalta mucho por estar hecha la operación sobre un papel granate.

39 Sirvan como ejemplo: "El puente romano de Reparacea, cerca de Bertizarana (1) se halla admirablemente conservado, salvando por este lugar el curso del Bidasoa y correspondiendo a algún ramal de las vías romanas, en comunicación con las Galias" (CASTRO, C. de.: Catálogo Monumental y Artístico de

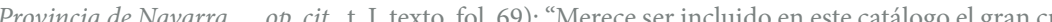
de talla que se venera en esta iglesia" (CASTRO, C. de. Catálogo Monumental y Artístico de la Provincia de Navarra..., op. cit., t. II, texto, fol. 78).

40 "Es muy notable el de "los Gladiadores", del Ayuntamiento de Pamplona, de gran expresión dentro de la gracia fiera de sus movimientos" (CASTRO, C. de.: Catálogo Monumental y Artístico de la Provincia de Navarra..., op. cit., t. I, texto, fols. 62 y 63).

41 "ESCULTURAS-BRONCES" (CASTRO, C. de.: Catálogo Monumental y Artístico de la Provincia de Navarra..., op. cit., t. I, texto, fol. 65); "RENACIMIENTO" (CASTRO, C. de.: Catálogo Monumental Artístico de la Provincia de Navarra..., op. cit., t. I, texto, fol. 112)

42 Al texto mecanografiado que decía "La pintura, notabilísima de escuela, tal vez sea de pocos años de la muerte del infortunado príncipe", le añadió: "en realidad es un San Sebastián cuya fisonomía recuerda la del desgraciado príncipe. Es por todo ello un ejemplar muy interesante”, (CASTRO, C. de.: Catálogo Monumental y Artístico de la Provincia de Navarra..., op. cit., t. II, texto, fol. 323).

43 A diferencia del catálogo de Logroño donde se fueron indicando en el texto sus correspondientes láminas, en el caso navarro las alusiones en este sentido fueron muy escasas y solo en el primer tomo y en las primeras hojas. Sirvan de ejemplo: CASTRO, C. de.: Catálogo Monumental y Artístico de la Provincia de Navarra..., op. cit., t. I, texto, fol. 21: referencias a las láminas 4, 6, 7 y 9; fol. 24 a las láminas 8, 9, 10, 11 y 12 .

44 Hay referencias a Lampérez y su Historia de la arquitectura cristiana en: CASTRO, $\mathrm{C}$ de: Catálogo Monumental y Artistic fols. $140,154,176$

4 CASTRO, C. de.: Catálogo Monumental y Artístico de la Provincia de Navarra..., op. cit., t. I, texto, fols. 133, 147 y 175. Ibid., t. II, texto, fol. 12.

\section{LAS FOTOGRAFÍA}

Castro presentó tres tomos de fotografías con un total de 419 imágenes: 161 correspondientes al primer tomo, 131 al segundo y 127 al tercero. Este material gráfico se ofrece dentro de un sencillo enmarque, tanto en tinta negra como roja, dejando un amplio margen alrededor. Para su identificación, manuscrita o mecanografiada, no se sigue un criterio unitario, titulando en general el objeto en el pie de la imagen, y la localidad, valle e incluso partido judicial en la parte superior, acompañado en ocasiones con la palabra Navarra ${ }^{46}$. Todas las fotografías están numeradas de manera correlativa sobre el ángulo superior derecho con lápiz, en lo que parece ser una operación posterior, como también creemos que lo es un pequeño apunte que figura en la parte inferior derecha aportando una referencia al correspondiente volumen de texto.

Algunos pies de las fotografías fueron enmendados, tachando la escritura original y añadiendo una corrección manuscrita. Desconocemos quién lo hizo y cuándo. Así, por ejemplo, en el caso de la catedral de Pamplona son varios los casos que de este modo puntualizan o subsanan la identificación original: la denominada en principio Puerta de las Flores se precisa que es la capilla Barbazana, como ocurre con lo que inicialmente se designa capilla de Xavier, donde se indica con posterioridad que se corresponde con el antiguo refectorio. La puerta "La Pretisa" se tacha para informar de su auténtico nombre, Preciosa, y el relicario de la Sagrada Espina se corrige para advertir de que realmente es el Lignum Crucis. Otras rectificaciones se perciben en otros templos de la capital, como en uno de los frontales de plata de la capilla de San Fermín, que en origen aparecía ligado a la propia seo. Pero también fuera de Pamplona hay enmiendas, como un ventanal gótico del palacio de los duques de Granada de Ega de Sangüesa que en origen se ligaba a los duques de Villahermosa. Ocurre incluso una doble corrección en una fotografía. Se trata del sepulcro de Pere Arnaut de Garro y su esposa vizcondes de Zolina, en el claustro de la catedral de Pamplona. El pie primitivo fue sustituido por una corrección en lápiz, que también fue tachada para, finalmente, comunicar que se correspondía con el sepulcro del bastardo de Carlos el Malo, el infante Lionel de Navarra, siguiendo así una creencia errónea que defendieron Arigita o el marqués de Lozoya ${ }^{47}$.

46 En el tomo I predominan los enmarques en negro y todas las fotografías están identificadas de maner manuscrita excepto las número 5, 77, 92, 108, 111, 119 y 122. Los tomos II y III tienen, por el contrario, una mayoría de enmarques en rojo. Asimismo, en ellos la mayor parte de las imágenes se identifican con letra mecanografiada, excepto la 166,167,169,170,171,178,179,206,212,241,242,243,244 y 247 del tomo II, y la 292, 293, 300 y 411 en el III.

47 MONTESA, M. de: "El sepulcro de Don Leonel", Príncipe de Viana, 19, 1945, pp. 148-149. 
Pero no todos los errores se subsanaron. Algunos quedaron para la posteridad y han llegado así hasta nuestros días. En unos casos las inexactitudes están ligadas a la identificación del objeto, como ocurre, por ejemplo, con el exterior de la parroquia de San Nicolás de Pamplona, que es identificada como la parroquial de San Lorenzo, el claustro del convento de Santo Domingo de la capital que aparece como la casa de Misericordia de Pamplona o el exterior de la cocina de la catedral de Pamplona que figura como la iglesia de Santiago de Sangüesa, en este caso tras haber sido enmendada la primera identificación que rezaba iglesia de Santa María la Real. En otras ocasiones, extendiendo lo que acontece en los tomos de texto, los desaciertos radican en la localización de la pieza. Es el caso de la Virgen con el Niño gótica de Huarte, que el autor sitúa como perteneciente a la localidad de Uharte Arakil, o la ubicación de un caserío baztanés -en realidad la torre Zubiria de Arraioz- que emplaza en el pirenaico valle de Roncal. No faltan tampoco confusiones con la advocación de los templos, como sucede con la parroquia de Nuestra Señora de la Purificación de Gazólaz, que Castro denomina de San Nicolás, reflejando el texto. Son también frecuentes las erratas en las denominaciones de localidades: Larrumbe (Larumbe), Lesa (Yesa), Gazolas (Gazólaz) o de iglesias, como San Pedro de la Ruá en Estella. Pero los desaciertos no corregidos se extienden también al estilo adjudicado en los pies de algunas piezas. Sirva como ejemplo la custodia gótica de Roncesvalles que figura bajo estilo Renacimiento, o la titular de la parroquia de Los Arcos, una imagen gótica que es identificada como Virgen bizantina, calificativo que también aplica a los capiteles románicos procedentes de la catedral de Pamplona. Finalmente debemos reseñar otro tipo de inexactitudes relevantes, como la colocación invertida de la marca de impresor de Arnao Guillén de Brocar, lo que supone situar sus iniciales y una cruz de remate boca abajo.

Si analizamos la distribución de las fotografías, Pamplona acapara buena parte de ellas, con un total de 82, a las que hay que sumar las 36 del entonces Museo Arqueológico, situado en la Cámara de Comptos, también en la capital, y otras 25 de documentos y sellos conservados en el Archivo provincial, anexo a la Diputación. Le sigue en número la colegiata de Roncesvalles con 34 imágenes y Estella con 33, ocupando las siguientes posiciones el monasterio de Leyre con 17, Sangüesa con 12, el monasterio de La Oliva con 11 y Olite con 10, descendiendo luego a una, dos o tres imágenes de algunos monumentos y/o municipios. Ante este panorama llama la atención la desproporción existente entre las distintas localidades navarras. Así, por ejemplo, de Tudela solo hay 7 imágenes, de las que 6 se corresponden a la catedral. Por el contrario, de la pequeña iglesia medieval de Gazólaz y sus bienes hay nada menos que 21 imágenes, como ocurre con la parroquia de Larumbe que ofrece 9 .
La visión que se ofrece a través de las fotografías nos muestra un concepto decimonónico del patrimonio, similar al desarrollado en el texto: un interés centrado exclusivamente en la Prehistoria, Antigüedad y, sobre todo, en la Edad Media, que acaparan la mayoría del repertorio. Por el contrario, son escasísimas las imágenes que se aportan sobre obras renacentistas, barrocas o neoclásicas.

La idea que exhibe Castro sobre el patrimonio aparece reducida prácticamente al monumento arquitectónico, lo que se plasma a través de la preeminencia de la arquitectura religiosa, especialmente medieval y de exteriores, aspecto este último lógico, dadas las dificultades y limitaciones que a principios del siglo XX existía todavía para captar fotográficamente los interiores. Ocupan también un lugar destacado entre las imágenes los puentes, con más de una quincena de ejemplares, así como algunas vistas y paisajes. En mucha menor medida están presentes algunas cuevas, dólmenes, mausoleos, retablos, murallas y castillos. Como testimoniales podemos calificar tanto la arquitectura doméstica como las artes decorativas: textiles, vidrieras, eboraria o platería que aparecen en número limitadísimo. Cabe destacar asimismo la presencia de dos fotografías con tipos humanos: una es identificada en su pie acertadamente como "Tipo de roncalesa con traje de fiesta". Por el contrario, la otra figura erróneamente como "Grupo de tamborileros roncaleses". A pesar de carecer de cualquier tipo de referencia, hemos podido constatar que se trata de una foto comercializada por J. Laurent $y$ Cía, que fue recortada para encajarla en este álbum. La imagen se corresponde en realidad con uno de los grupos o comparsas que, vestidos con trajes populares, acudieron desde distintas regiones de España a Madrid con motivo de la boda de Alfonso XII y María de las Mercedes en 1878 y que el fotógrafo francés inmortalizó por encargo de la Sociedad Antropológica española. Una copia conservada en el Museo Nacional de Antropología, lleva como título Navarre. 1950. Grupe de paysans de Navarre et Bizcaye (INV. FD2878) ${ }^{48}$. Desconocemos si el origen de los hombres retratados como navarros y vizcaínos era el correcto, pero podemos afirmar que ni los tipos ni sus indumentarias eran desde luego roncaleses ${ }^{49}$.

48 SÁNCHEZ VIGIL, J. M., OLIVEIRA ZALDÚA, M. y LÉON-SOTELO Y AMAT, M. T. de: La colección fotográfica Laurent en el Museo Textil de la Universidad Complutense de Madrid. Tipos y trajes populares. Madrid, Universidad Complutense, 2009, pp. 19-20. DÍAZ FRANCÉS, M.: J. Laurent, 1816-1886. Madrid, Ministerio de Educación, Cultura y Deporte, 2016, pp. 408-411.

49 Agradecemos al doctor José Ignacio Riezu Boj su asesoramiento sobre indumentaria y tipos roncaleses y a la doctora Maite Díaz Francés sus aportaciones sobre el fotógrafo Laurent. Esta fotografía puede verse en: http://ceres.mcu.es/pages/ResultSearch?txtSimpleSearch=NAVARRE._1950._Groupe\%20 de\%20paysans\%20de\%20Navarre\%20et\%20Bizcaye.\&simpleSearch=0\&hipertextSearch=1\&search=simple\&MuseumsSearch=\&MuseumsRolSearch=1\&listaMuseos=null (consultado el 6/5/2019). 
No resulta complejo rastrear el origen del conjunto fotográfico presentado por Castro pues él mismo nos ofrece información en la introducción del catálogo. Y así señala que a los cientos de fotografías que realizó el fotógrafo que le acompañaba, Miguel España, se unían las adquiridas de manos de "los señores Lacoste, Roldán, Pliego y Mena”, así como las facilitadas por Florencio Ansoleaga, Jesús Etayo, director del Archivo provincial, el Padre Pedro de Madrid y Julio Altadill, a quien agradecía expresamente que le hubiera entregado "numerosos clichés de su propiedad y otros en nombre de la Comisión de monumentos" 50

Tras haber revisado cuidadosamente el archivo fotográfico de la citada comisión, así como el fondo particular de Altadill, ambos custodiados en la actualidad en el Archivo Real y General de Navarra, podemos afirmar que, en efecto, fueron abundantes las fotografías facilitadas por Altadill y realizadas por él mismo, procedentes tanto de su propia colección como de la Comisión de Monumentos, de la que era vicepresidente y a la que alimentaba asiduamente con documentación gráfica ${ }^{51}$. Así comprobamos, por ejemplo, que de su propiedad eran las fotografías del castillo de Marcilla, la portada de la parroquia de San Román de Cirauqui, el ayuntamiento de Pamplona, algunas piezas procedentes de los dólmenes de Aralar custodiadas entonces en el Museo arqueológico, el báculo del obispo de Patrás de la iglesia de San Pedro de la Rúa de Estella o la imagen de la joven ataviada de roncalesa. A ellas podemos unir el Estado y descripción de la santa iglesia catedral de Pamplona, que figura con el pie "Portada de uno de los más famosos libros impresos en Pamplona por Juan de Oteyza”, y la marca del impresor Tomás Porralis de Saboya, en cuya identificación Castro demostró sus escasos conocimientos sobre patrimonio documental y bibliográfico, al denominarla códice. Pero lo más grave se encuentra ligado con la reproducción de ocho fotografías aportadas por Altadill que recogían documentos medievales custodiados en el entonces Archivo provincial. Todas ellas, menos una, fueron identificados erróneamente por Castro, poniendo de manifiesto, por un lado, que ni leyó ni interpretó dichos documentos, y, por otro, que sus nociones de paleografía eran escasas o nulas, al confundir, por ejemplo, documentos del siglo XIII con otros del siglo XV, y otros de esa centuria con la obra del historiador Arnaldo de Oihenart ${ }^{52}$. Evidenciaba con ello

50 CASTRO, C. de: Catálogo Monumental y Artístico de la Provincia de Navarra..., op. cit., t. I, texto, fols. 8-9. 51 Sobre su afición a la fotografía: CÁNOVAS, C.: Navarra Fotografía. Pamplona, Gobierno de Navarra 2012, pp. 76-83.

52 Enumeramos a continuación los documentos que Castro identificó de manera errónea, situando en primer lugar el título que figura en la ficha catalográfica del AGN y añadiendo entre paréntesis el pie que escribió Castro en el catálogo: Acuerdo entre los reyes Fernando III de Castilla y Teobaldo I de Navarra para un proyectado matrimonio entre los infantes Alfonso y Blanca ("Carta de Carlos el Noble además, el incumplimiento del artículo 9 del Real Decreto de 14 de febrero de 1902 donde se indicaba que "los Comisionados deberán examinar cuidadosamente los documentos impresos o manuscritos, en particular los que se conservan en los Archivos nacionales, municipales, eclesiásticos y particulares". El quebrantamiento de este artículo era doble pues, asimismo, la norma jurídica señalaba que "la descripción de los monumentos se presentará ilustrada con planos, dibujos y fotografías"53. Sin embargo, Castro no exhibió ni un solo plano y ofreció exclusivamente fotografías de los bienes, excepto en tres casos donde reprodujo el dibujo de unas monedas romanas y dos sellos reales medievales ${ }^{54}$.

Ejecutadas también por Altadill, pero procedentes de la Comisión de Monumentos, Castro también aprovechó las bellas imágenes del claustro de San Pedro de la Rúa de Estella, del claustro del antiguo convento de Santiago de Pamplona, las correspondientes al derruido monasterio de Iranzu, la puerta La Gallarda de Estella, las ruinas del convento de Santo Domingo de Estella, la iglesia de Santa María de Zamarce o la ermita de Osquía. Hemos podido asimismo comprobar que hay otro conjunto de fotografías en el catálogo que tienen también a Altadill como autor, aunque no se han conservado ni en su fondo particular $n$ en el de la comisión. Sin embargo, no hay duda de su autoría porque fueron publicadas también en su Geografía general del País Vasco-navarro. Provincia de Navarra, situando en su pie la expresión "clisé de Altadill". De estas, aprovechó Castro algunas correspondientes a monedas, mosaicos, esculturas y lápidas romanas, la puerta de la Taconera y la basílica de San Ignacio en Pamplona, o una vista del valle del Roncal, por citar solo algunos ejemplos.

a la Navarrería". Catálogo, t. I, foto 123). Carta de fray Godofredo, maestre de la Orden de San Juan de Jerusalén, al rey Sancho VII de Navarra ("Donación de don Juan y de doña Blanca", Catálogo, t. I, foto 124). Concesión otorgada por los reyes Juan II y Blanca de Navarra a los vecinos de San Juan de Pie de Puerto de exención en el pago de peajes ("Documento relativo a don Luis de Beaumont" Católogo, to I, foto,125). Confin de la exención del pago de cermenaje que les había concedido su padre Carlos II ("Escritura del A naldo Ohienart" y "Otra escritura del propio historiador", Catálogo, t. I, fotos, 126 y 127). Carta de fray Godofredo, maestre de la Orden de San Juan de Jerusalén, al rey Sancho VII de Navarra ("Privilegio de don Teobaldo al conde de Olite", Catálogo, t. I, foto 129). Carta de fray Godofredo, maestre de la Orden de San Juan de Jerusalén, al rey Sancho VII de Navarra ("Carta de doña Blanca a los caballeros de las Buenas Villas, Catálogo, t. I, fol. 130). Solamente identifica de manera correcta la concesión de tregua por Fernando III de Castilla, atendiendo la demanda de los emisarios del rey Teobaldo I de Navarra que titula como "Negociaciones de Fernando de Castilla y Teobaldo" (Catálogo, t. I, foto 128).

53 Real Decreto de 14 de febrero de 1902 para la continuación del Inventario general de los Monumentos históricos y artísticos del Reino (Gaceta de Madrid, n. ${ }^{\circ} 49$, pp. 734-735, 18-II-1902).

54 CASTRO, C. de.: Catálogo Monumental y Artístico de la Provincia de Navarra..., op. cit., t. I, fotos 21 145 y 146 
Dejando a un lado a Altadill, hemos podido asimismo verificar que otro importante conjunto de imágenes del catálogo procedían de la Comisión de Monumentos y eran obra a diversos fotógrafos. Dado que la institución no poseía los clichés, probablemente Castro seleccionó de sus fondos las fotografías que le interesaban -o le recomendaron- y recurrió a su adquisición de manos de sus autores. Entre ellas hemos identificado obras de José Roldán Bidaburu y de su estudio (el pórtico de la parroquia de San Román de Cirauqui, la ermita de Nuestra Señora de Eunate, Santa María de Sangüesa, la panorámica de Santa María de Ujué y su portada, la iglesia de San Pedro de Olite, el ábside del monasterio de Irache y varias del monasterio de Leyre), y de Emilio Pliego (ventana del palacio de los duques de Granada de Ega de Sangüesa y claustro del monasterio de La Oliva), que se corresponden con los fotógrafos más destacados del panorama navarro de la época ${ }^{55}$. El cordobés compró también varias imágenes a José Juan M. ${ }^{a}$ Lacoste Bordé, quien en torno a 1900 se había hecho cargo del establecimiento madrileño del fotógrafo francés Laurent. De esta firma procedían dos fotografías del monasterio de Irache, una del palacio de Olite, el Cristo de Anchieta de la catedral de Pamplona y la fotografía de los supuestos tamborileros roncaleses ${ }^{56}$.

Del capuchino fray Pedro de Madrid era una fotografía de la torre Zubiria en la localidad baztanesa de Arraioz, procedente de una colección que el fraile presentó sobre caseríos baztaneses bajo el título Echezarra en un certamen fotográfico celebrado en Pamplona en 1912 en el marco del VII centenario de las Navas de Tolosa ${ }^{57}$. Finalmente se adjuntaron al catálogo otras imágenes que poseía la comisión y cuya autoría resulta anónima, como algunas de la iglesia de Larumbe y del palacio real de Olite. Desconocemos si las fotografías que conformaban la colección de la comisión habían sido adquiridas o, si por el contrario,

55 Sobre Roldán y Pliego, puede verse: CÁNOVAS, C.: op. cit., pp. 51-54 y 59-64.

56 Lacoste mantuvo el negocio hasta 1915 en que se lo traspasó a Juana Roig Villalonga: DÍAZ FRANCÉS, M.: I. Laurent (1816-1886) Fotógrafo, empresario y editor gráfico en la España del siglo XIX. Vol. I, Pamplona, Universidad de Navarra (tesis doctoral), 2015, pp. 165-171. Sobre la relación de Laurent con Navarra: DÍAZ FRANCÉS, M.: "Aportaciones de la casa Laurent a la fotografía navarra del siglo XIX" Cuadernos de la Cátedra de Patrimonio y Arte navarro, 3, 2008, pp. 729-739.

57 AGN, CMHAN, caja 17: Actas de la comisión, t. III, s. f. En las sesiones de 31 de diciembre de 1916 y 20 de enero de 1917 se acordó solicitar al colegio de capuchinos de Lekaroz una copia de la serie. En la sesión de 6 de marzo de 1917, Altadill informaba de que iba a visitar en Córdoba a fray Pedro de Madrid para hacerse con las fotografís. Finalmente, en sesión de 24 de abril daba cuenta a la comisión de para hacerse con de recepción de las fotog Fr. Pedro de Madrid, 1912", Revista de Dialectología y Tradiciones Populares, 68, 2, 2013, pp. 385-422, especialmente 394 habían sido regaladas por sus autores. Nada nos dicen las actas de la institución. Sin embargo, nos inclinamos a pensar que fueron dádivas, pues en la sesión de 31 de diciembre de 1916 -en fechas por tanto paralelas a la ejecución del catálogo- Altadill declaraba que

"cuando adquiera una lista, que espera sea en breve de los muchos buenos aficionados a la fotografía que hay en Navarra, tiene el propósito de pedir a todos ellos que regalen para el Museo de esta Comisión vistas fotográficas de los monumentos, esculturas, restos arquitectónicos, cuadros y toda clase de objetos existentes en esta provincia y que puedan interesar bajo el punto de vista de la historia o del arte"58.

De hecho, a continuación "manifestó que los señores Roldán e hijo, fotógrafos de esta ciudad, le habían prometido, hace algún tiempo, regalar a esta comisión una colección de fotografías de caseríos, castillos y monumentos notables existentes en Navarra para enriquecer la del Museo" ${ }^{\prime \prime}$.

En conjunto, las fotografías del catálogo resultan muy desiguales, tanto en calidad como en tamaño. No obstante, es necesario destacar el incuestionable valor estético de algunas de ellas como las correspondientes al claustro de San Pedro de la Rúa de Estella, del claustro de la catedral de Pamplona o de Santa María de Eunate, así como el valor documental que aportan otras por ofrecernos imágenes anteriores a las restauraciones o remodelaciones desarrolladas a lo largo del siglo XX. Es el caso de los monasterios de Leyre, Iranzu, La Oliva, los claustros de la catedral de Tudela y de Santa María de Olite, la colegiata de Roncesvalles, las basílicas de Nuestra Señora del Puy de Estella y de San Ignacio de Pamplona, el castillo de Javier, las fortificaciones de Pamplona o el interior de la catedral de Pamplona.

\section{ANÁlisis deL CATÁlOGO}

El objetivo propuesto por Castro con este catálogo era, tal y como él mismo explicaba, "estudiar someramente las épocas y sus periodos arqueológicos con carácter sintético para después, en lo que propiamente debe llamarse inventario proceder a la catalogación de

8 AGN, CMHAN, caja 17: Actas de la comisión, t. III, s. f., sesión de 31 de diciembre de 1916. 9 Ibid. 
cada monumento, con la extensión que requiera su importancia”. Y, efectivamente, as procedió en la estructura de su trabajo ofrecido en dos tomos. Tras una introducción, dividió su trabajo en dos partes. En la primera, plasmada en el tomo I, recorrió la historia de Navarra, desarrollando para ello cuatro capítulos (los orígenes de Navarra -capítulo I-, la etapa romana -capítulo II-, la dominación cristiana y orígenes de la monarquía navarra -capítulo III-, y un cuarto capítulo que tituló el Reino de Navarra, donde incluyó algunos datos históricos, así como tres subapartados dedicados a lo que él denominaba la época románica, la época ojival y la época moderna. Ya en la segunda parte recogió el patrimonio artístico de Navarra, realizando lo que calificaba indistintamente catálogo o inventario, confusión terminológica habitual por aquellas fechas en nuestro país, tal y como atestiguan los propios decretos de 1900 y 1902 que regulaban la ejecución del catálogo español, que emplearon aleatoriamente ambos vocablos, convirtiéndolos en sinónimos. Arrancó su catalogación con Pamplona -capítulo V-, centrándose fundamentalmente en la catedral, a la que dedicó una gran extensión, resultando muy desproporcionada respecto al resto del patrimonio de la ciudad. No obstante, también se refirió a los templos parroquiales y a algunos edificios civiles, deteniéndose en la Diputación, el Ayuntamiento, la Casa de Misericordia, el Hospicio, el Archivo histórico, la Cámara de Comptos que acogía el Museo arqueológico, el monumento a los fueros, el Palacio episcopal y el Palacio de Justicia. En el tomo segundo continuó con la catalogación del patrimonio del resto de Navarra, ordenando la entonces provincia a través de partidos judiciales: Pamplona, Aoiz, Estella, Tafalla y Tudela, dentro de los que siguió un orden alfabético de los valles y localidades que resultaban, según su criterio, dignos de mención.

Tras haber leído y analizado con detenimiento el catálogo navarro, podemos afirmar que Castro mostró constantemente falta de formación histórica, ausencia de metodología científica e incapacidad para analizar el patrimonio, desvelando importantes lagunas en su conocimiento de la historia del arte y mirada miope para distinguir estilos, autorías, etc. Indudablemente Castro siguió muy de cerca para desarrollar la parte histórica la obra de Arturo Campión y su visión idílica y mitificada de la Navarra medieval y del pueblo euskaro, sin llegar a explicar, por ejemplo, el fin de la monarquía navarra y cometiendo anacronismos significativos como situar a Íñigo Arista a la cabeza de los vascones que vencieron a Carlomagno en Roncesvalles ${ }^{60}$. Por su parte, los aspectos prehistóricos los tomó

60 CASTRO, C. de.: Catálogo Monumental y Artístico de la Provincia de Navarra..., op. cit., t. I, texto, fols. 83-85 fundamentalmente de Iturralde, así como de Aranzadi y Ansoleaga. Utilizó en esta parte denominaciones como aborígenes y trogloditas para referirse a las primeras poblaciones y recogió diversos dólmenes con los hallazgos de sus excavaciones.

Para la elaboración del catálogo se basó en gran medida en dos obras: Provincia de Navarra, de Julio Altadill, correspondiente a la colección Geografía general del País Vasco-Navarro, dirigida por Francisco Carreras y Candi, y España, sus monumentos y artes. Su naturaleza Historia. Navarra y Logroño, de Pedro de Madrazo. De manera más puntual unió también Las grandes ruinas monásticas de Navarra, de Juan de Iturralde y Suit. En líneas generales informaba sobre las fuentes empleadas en los grandes monumentos, tanto las tres citadas como otras ocasionales, utilizando a menudo el entrecomillado para citas textuales, bastante habituales por otra parte. No faltaron, no obstante, auténticos plagios donde copió literalmente a los mencionados autores sin citarlos. Es el caso, por ejemplo, de las descripciones completas de la Puerta del Amparo o el sepulcro de Carlos III en la catedra de Pamplona, donde reprodujo con exactitud, palabra por palabra, a Altadill, sin mencionar la fuente y sin aportar entrecomillado alguno ${ }^{61}$. Lógicamente, siguiendo esta dinámica y ante la falta de investigación propia, reprodujo los mismos errores que habían mostrado estos autores. Sirvan como ejemplo la cronología del claustro de la catedral de Pamplona, que consideró, como Altadill y Madrazo, obra del siglo XIV en lo correspondiente a las cruíías norte y este, promovidas por el obispo Barbazán, y al siglo XV las del sur y oeste, patrocinadas además, según ellos, por Carlos III. Y lo mismo ocurre con el sepulcro en la misma seo de Pere Arnaut de Garro y su esposa, que adjudicó al infante Lionel de Navarra hijo de Carlos II, como hacían ambos autores, o con la bóveda de la iglesia de Santiago de Puente la Reina, que fechó en el siglo XV siguiendo en este caso a Madrazo ${ }^{62}$.

Nos hallamos ante un trabajo que denota en no pocas ocasiones, especialmente en la parte histórica y en la descripción de localidades, un estilo literario más propio de un periodista y escritor que de un historiador del arte. El catálogo adolece de abundantes errores, vaguedades, imprecisiones y carencias significativas. Veamos algunos ejemplos.

61 Ibid., fols. 140-144 y 153-155. ALTADILL, J.: Provincia de Navarra, Barcelona. Establecimiento editorial de Alberto Martín, [s.a.], pp. 754-757 y 761-762.

62 CASTRO C de. Catálogo Monumental y Artístico de la Provincia de Navarra op. cit., t. I, texto, fols. 133 134, 158-159. Ibid., t. II, fol. 64. ALTADILL, J.: op. cit., pp. 764-765. MADRAZO, P.: España, sus monumentos $y$ artes. Su naturaleza e Historia. Navarra y Logroño. t. II, Barcelona, Editorial de Daniel Cortezo, 1886, pp. 273, 286-288, 290-291. 
Las erratas constatadas a lo largo del texto son continuas y oscilan desde las copiosas faltas ortográficas hasta inexactitudes en los nombres de algunas localidades (Arrázuri en vez de Arazuri, Villalba en vez de Villava, Badestáin en vez de Badostáin, Idecin en vez de Idocin, Laca en vez de Lácar, Torres de Sansol cuando en realidad se trata de dos localidades distintas aunque muy cercanas), pasando por equivocaciones geográficas (como la ubicación de Uharte Arakil cerca, según decía, de la carretera de Roncesvalles, o Villamayor de Monjardín en el partido judicial de Aoiz), y otras relativas a las advocaciones de las iglesias (parroquia de San Nicolás de Gazólaz en vez de la Purificación, o Santa María del Puig en vez de Puy) o en los nombres de las órdenes religiosas (agustinas reales de Pamplona para referirse a las agustinas recoletas, salesianas en vez de salesas, también en la capital, recoletas descalzas de Tafalla para aludir a las concepcionistas recoletas, mientras en Corella señalaba la presencia de benedictinas y de recoletas de San Benito, inexistentes estas últimas, dejando por el contrario sin reflejar a las carmelitas descalzas del convento de Araceli).

Desaciertos e inexactitudes se ponen de manifiesto igualmente al clasificar estilísticament algunas obras, demostrando su desconocimiento sobre historia del arte. Así por ejemplo, definió como churrigueresco el retablo romanista de la parroquia de Alsasua, o como borrominesco el también romanista de Mendigorría, mientras ofrecía como renacentistas los retablos barrocos de Roncal y Viana o el rococó de la iglesia de Santiago de Sangüesa. Los deslices, algunos de gran calado, se suceden a lo largo de los dos tomos. Y así, calificó como romano el puente medieval de Reparacea, tildó como borrominesca la torre renacentista de Los Arcos, clasificó como renacentista la custodia gótica de Roncesvalles y situó en el siglo XV el palacio dieciochesco del marqués de Feria de Tafalla, mientras la parroquia San Miguel de Corella, sin duda uno de los conjuntos barrocos más sobresalientes de la provincia, la catalogó como del románico de transición.

A su incapacidad para identificar correctamente estilos artísticos, se unió su incompetencia para detectar sus fases y evolución, así como para distinguir la presencia de diversas manos Un ejemplo muy elocuente lo hallamos cuando se refirió al escultor romanista Juan de Anchieta (h. 1533-1588), según él llamado Miguel de Anchieta y muerto en 1530, es decir antes de la fecha de su nacimiento. A él le adjudicó la sillería de coro de la catedral de Pamplona y le otorgó un estilo como el de Berruguete. Pero lo cierto es que la obra fue contratada en 1539 por el artista francés Esteban de Obray, quien, en compañía de un amplio equipo, la desarrolló en un estilo renacentista previo al romanismo. Por el contrario, adjudicó correctamente a Anchieta el Cristo de anatomía hercúlea que entonces había en el trascoro, clasificándolo como "obra preeminente" y señalando, erróneamente, que su estilo recordaba al de Alonso Cano. Líneas después no solo no fue capaz de identificar como obra del escultor vasco un grupo de San Jerónimo penitente custodiado en la misma seo, sino que además señaló que "deja mucho que desear"63.

Las vaguedades e imprecisiones se revelan en la escasez de cronologías y adscripciones estilísticas, especialmente cuando se sale de los grandes monumentos navarros y no tiene referencias bibliográficas en las que apoyarse. Utilizó entonces a menudo expresiones como "época de transición" para cualquier siglo (parroquias de Garde, Roncal o Liédena), "estilo greco-romano" para edificios tanto renacentistas como barrocos (casa consistorial de Viana, parroquia del Rosario de Corella o palacio de los Gómara en Valtierra), calificativos como borrominesco o churrigueresco para cualquier manifestación del Barroco, o como mezcla de estilos cuando se hallaba ante un templo con varias fases constructivas (iglesia parroquial de Alsasua), e incluso aunque el edificio respondiera a un único momento constructivo, como ocurría con la parroquia de Larraintzar, erigida en el siglo XIX. Algunos calificativos resultan ciertamente sorprendentes, como el "estilo pseudo-clásico y pseudoartístico" que adjudicó a la casa consistorial de Bera. No faltan a menudo descripciones vacuas sin aportación catalográfica alguna. Así, por ejemplo, en relación con el exorno de la parroquia de Doneztebe/Santesteban recoge el "magnífico retablo con la escultura de San Pedro" o el "coro verdaderamente sorprendente por la delicadeza y suntuosidad de sus labores", mientras de la imagen de Nuestra Señora del Romero de Cascante dice simplemente que "es de talla", sin ofrecer en ninguno de los casos mencionados descripción ni adscripción alguna.

Junto con estas aportaciones existen otras que ofrecen también imprecisiones y errores, lo que nos hace sospechar que no visitó todas las localidades que aparecen en el texto. Los casos se suceden, aunque ahora nos limitaremos a citar solo algunos ejemplos: en la parroquia de Etxalar habló de una bóveda de cañón, siendo estrellada, en la de Lesaka donde recogió unos supuestos escudos platerescos, reflejó una iglesia de tres naves, cuando es de una, mientras refería columnas salomónicas, inexistentes, en el retablo rococó de Lerín. Que no recorrió, por ejemplo, los pueblos de la Ribera de Navarra, o al menos era incapaz de relacionar unas obras con otras, se demostró cuando calificó de "curiosísimos relieves" los enmarques barrocos en los vanos de la casa de las Cadenas de Corella, siendo, en realidad, muy habituales en la arquitectura señorial de ladrillo en buena parte del

63 CASTRO, C. de.: Catálogo Monumental y Artístico de la Provincia de Navarra..., op. cit., t. I, texto, fols $164-165$ y 167 
valle del Ebro. Otras afirmaciones nos inclinan igualmente a creer que muchas localidades navarras, especialmente pequeños núcleos rurales, quedaron sin su examen. Así creemos deducirlo cuando señalaba que la mayor parte de los palacios cabo de armería de Navarra eran renacentistas. Aunque es cierto que existen importantes ejemplares del siglo XVI, otros muchos de la denominada nómina antigua son torres del siglo XV y los de nómina nueva se corresponden en gran medida con construcciones palaciegas del siglo XVIII. Pero una de sus afirmaciones más atrevida, y a la vez desafortunada, se plasmó a través de una frase lapidaria: "no abundan en Navarra los monumentos de la época Moderna"64, siendo para él el más característico la basílica de San Gregorio Ostiense, que calificó además de monasterio y omitiendo obras de gran envergadura como por ejemplo la capilla de la Virgen del Camino en Pamplona, por citar solo un ejemplo muy significativo y en la propia capital. Si visitó toda Navarra, ¿acaso no vio las manifestaciones renacentistas y barrocas o no las supo identificar? Tal y como hemos comprobado, en nuestra opinión confluyeron ambos hechos.

Indiscutiblemente nos hallamos ante un trabajo muy incompleto en el registro de patrimonio, donde numerosas localidades con obras destacadas ni siquiera son nombradas. El catálogo ofreció una visión todavía muy decimonónica del patrimonio, centrada sobre todo en la arquitectura y dentro de ella especialmente en los edificios medievales, como las catedrales de Pamplona y Tudela, los grandes monasterios (Leyre, Irache, Iranzu, La Oliva y Fitero), algunos templos destacados como los de Sangüesa y Estella o la colegiata de Roncesvalles. Desproporcionadas resultan por su extensión en relación con otro monumentos las páginas que dedicó a pequeñas iglesias rurales como las de Gazólaz o Larumbe. No obstante, y a pesar de esta clara inclinación hacia los siglos del medievo, se omiten obras significativas. Sirvan como ejemplo relevantes iglesias y ermitas rurales como las de Artaiz, Aibar, Vesolla, Echano, Santiago de Itxasperri, San Zoilo en Cáseda, el antiguo monasterio de Azuelo, el monasterio de Tulebras, torres medievales como la de Celigüeta u Olcoz, así como diversos señoríos, sin olvidar piezas muy destacadas de la platería gótica como las custodias de Sangüesa y Aibar. Pero junto a este posicionamiento, Castro ofreció, además, otra perspectiva que hundía sus raíces en el academicismo dieciochesco, como si de un nuevo Ponz se tratara: el desprecio absoluto hacia el arte de los siglos XVII y XVIII que describe "como feudo de la extravagancia o del mal gusto, del churriguerismo y del barroquismo, del pseudo clasicismo" ${ }^{35}$. A lo largo del trabajo son varias las descalificaciones que hace de este estilo, lo que también se expone en la casi nula referencia a la arquitectura conventual, la arquitectura doméstica y las artes decorativas barrocas. Aunque no despreció expresamente el Renacimiento, tampoco recogió obras relevantes del siglo XVI como algunos palacios -el de los Mariscales de Navarra en Tafalla o la casa del Almirante de Tudela-, o retablos como el de Fitero o el de la catedral de Pamplona.

Esta visión tan restrictiva del patrimonio contrasta desde luego con la legislación vigente entonces, evidenciando una vez más la incapacidad y desconocimiento de Castro. No podemos perder de vista que en la Ley de Conservación de Monumentos arquitectónicos artísticos de 4 de marzo de 1915 -por tanto, aprobada justo antes de que Castro redacta el catálogo navarro- se reconocía como tales "los de mérito histórico o artístico, cualquiera que sea su estilo" ${ }^{66}$, haciendo desaparecer la perspectiva arqueológica y medieval existente previamente, y eliminando cualquier restricción cronológica y estilística del patrimonio La perspectiva ofrecida por Castro no reflejaba tampoco el enriquecimiento que en los años inmediatamente anteriores estaba viviendo el concepto de patrimonio. De hecho, se aprecia en las primeras décadas del siglo un progresivo interés por la arquitectura popular o tradicional, por las obras de ingeniería e incluso por la arquitectura contemporánea ${ }^{67}$. Este engrosamiento, junto con el creciente interés por el valor cultural de los bienes, quedaría reflejado muy pocos años después en el Real Decreto Ley de 9 de agosto de 1926, que, con una visión muy moderna, consideraría el Tesoro artístico arqueológico nacional como "el conjunto de bienes muebles e inmuebles dignos de ser conservados para la Nación por razones de Arte y cultura"68, dejando por tanto totalmente obsoleta y caduca la visión de Castro. Esta discordancia no solo evidencia una visión ya anquilosada y trasnochada del autor cordobés, sino que también delata que los catálogos, que habían nacido en 1900 como herramienta de protección del acervo monumental, no resultaban operativos, no solo por la evolución y enriquecimiento conceptual del monumento, que dejaba desfasado el contenido de los catálogos, sino también porque a la protección genérica del patrimonio basada en los catálogos, le sucederían para su defensa las declaraciones individuales ${ }^{69}$.

Ante los escasos y dispares resultados obtenidos desde 1900, la Ley de Patrimonio Artístico Nacional de 1933, vigente hasta 1985, siguió insistiendo en la importancia de los inventarios, tanto a través de los catálogos monumentales como del novedoso Fichero de Arte Antiguo.

66 Gaceta de Madrid n. 64 , p. 708, 5-III-1915.

67 MUÑOZ COSME, A.: op. cit., pp. 17-20.

8 Gaceta de Madrid, n.o 227, p. 1027, 15-VIII-1926.

69 MUÑOZ COSME, A.: op. cit., p. 36. GONZÁLEZ-VARAS, I.: op. cit., pp. 80 y 512. 
A ella se unieron otras disposiciones en las siguientes décadas que tuvieron como resultado la elaboración y publicación de numerosos inventarios provinciales a partir de los años sesenta, empresa dirigida desde el Servicio Nacional de Información Artística, Arqueológica y Etnológica ${ }^{70}$. Por su parte, en Navarra pronto se vio que la obra de Castro había resultado un fracaso. Así lo pone de manifiesto el encargo que hizo la Comisión de Monumentos casi de manera inmediata, en 1919, para redactar un "Índice de los Monumentos Históricos y Artísticos de Navarra” y dos años después “un catálogo de objetos artísticos clasificándolos en vendibles y no vendibles", nuevamente sin resultados a pesar de incorporar el apoyo económico de la Diputación Foral ${ }^{71}$. A partir de 1959, la Institución Príncipe de Viana retomó las labores de catalogación, centrándose en la documentación fotográfica de la mano de José Esteban Uranga. Afortunadamente, en 1977, en una experiencia única en el país por la colaboración de varios organismos e instituciones (Universidad de Navarra Gobierno de Navarra y Arzobispado de Pamplona), la catedrática M. ${ }^{a}$ Concepción García Gainza puso en marcha y dirigió un equipo de investigación formado por historiadores del arte (Jesús Rivas, M. ${ }^{a}$ Carmen Heredia, Mercedes Orbe, Asunción Domeño y José Javier Azanza) que, siguiendo los criterios de totalidad y exhaustividad, trabajó durante veinte años para alumbrar el definitivo Catálogo Monumental de Navarra. Fue publicado entre 1980 y 1997 a través de nueve volúmenes que recorrían las cinco merindades, logrando compendiar todo el patrimonio histórico-artístico de Navarra, habiéndose convertido en un referente en la catalogación de bienes culturales en España ${ }^{72}$. En la actualidad la Comunidad Foral cuenta también con el Inventario Arquitectónico de Navarra, iniciado en 2001, que actúa como herramienta de gestión administrativa e instrumento sistemático de conocimiento para la protección y conservación de su patrimonio arquitectónico ${ }^{73}$.

\section{CONCLUSIONES}

El Catálogo Monumental y Artístico de la provincia de Navarra, ejecutado por el periodista y escritor Cristóbal de Castro entre 1916 y 1917 y desarrollado a través de cinco volúmenes (dos de texto y tres de fotografías), fue una gran oportunidad perdida para identificar, registrar, conocer, y por tanto proteger, el patrimonio navarro. La restricción cronológica y la pobreza conceptual que tenía Castro sobre el patrimonio, en contraposición con la legislación coetánea, dejó fuera de la obra buena parte de los bienes muebles e inmuebles navarros, ofreciendo en consecuencia unos resultados incompletos y fragmentarios, a lo que se sumaron multitud de errores y carencias derivadas de su falta de profesionalidad, preparación científica, metodología y criterio.

70 Ley de 13 de mayo de 1933 relativa al Patrimonio Artístico Nacional, art. 66 (Gaceta de Madrid, n. ${ }^{\circ} 145$ pp. 1394-1399, 25-V-1933). Sobre la legislación y la evolución de los inventarios y catálogos en España durante el siglo XX: GONZÁLEZ-VARAS, I.: op. cit., pp. 81-84. LÓPEZ-YARTO ELIZALDE, A.: op. cit., pp. 73-76.

71 QUINTANILLA MARTÍNEZ, E.: op. cit., pp. 341-342

72 GARCÍA GAINZA, M. C. y OTROS: Catálogo Monumental de Navarra, 9 vols., Pamplona, Institución Príncipe de Viana, 1980-1997. GARCÍA GAINZA, M. C.: "Catálogo monumental de Navarra", Anuario de Historia de la Iglesia, 8, 1999, pp. 371-374.

73 CAÑADA PALACIO, F. y CIGANDA ELIZONDO, R.: "Inventario Arquitectónico de Navarra, una herramienta integral para la gestión del patrimonio inmueble", Príncipe de Viana, 262, 2015, pp. 973-984 


\section{BIBLIOGRAFÍA}

ALTADILL, J.: Provincia de Navarra, Barcelona. Establecimiento editorial de Alberto Martín, [s.a.].

AZANZA LÓPEZ, J. J. y SAN MARTÍN CASI, R.: “Casa, familia y heredad. La colección fotográfica de caseríos vascos de Fr. Pedro de Madrid, 1912", Revista de Dialectología y Tradiciones Populares, 68, 2, 2013, pp. 385-422.

BENITO LOPE, R., “Conservación y restauración de los originales del Catálogo Monumental de España”, en El Catálogo Monumental de España (1900-1961). Investigación, restauración y difusión. Madrid, Ministerio de Educación, 2012, pp. 127-149.

CÁNOVAS, C.: Navarra. Fotografía. Pamplona, Gobierno de Navarra, 2012.

CAÑADA PALACIO, F. y CIGANDA ELIZONDO, R.: "Inventario Arquitectónico de Na varra, una herramienta integral para la gestión del patrimonio inmueble", Príncipe de Viana, 262, 2015, pp. 973-984.

CASTRO, C. de: Catálogo Monumental y Artístico de la Provincia de Logroño, 2 vols., 1916.

CASTRO, C. de: Catálogo Monumental y Artístico de la provincia de Navarra, 5 vols. 1916-1917.

CRUZ CASADO, A.: "Cristóbal de Castro Gutiérrez", en Diccionario biográfico de la Real Academia de la Historia, http://dbe.rah.es/biografias/11626/cristobal-de-castro-gutierrez (consultado el 15/03/2019).

DÍAZ FRANCÉS, M.: "Aportaciones de la casa Laurent a la fotografía navarra del siglo XIX”, Cuadernos de la Cátedra de Patrimonio y Arte navarro, 3, 2008, pp. 729-739.

DÍAZ FRANCÉS, M.: J. Laurent (1816-1886) Fotógrafo, empresario y editor gráfico en la España del siglo XIX. Vol. I, Pamplona, Universidad de Navarra (tesis doctoral), 2015.

DÍAZ FRANCÉS, M.: J. Laurent, 1816-1886. Madrid, Ministerio de Educación, Cultura y Deporte, 2016
DÍEZ PATON, E.: "La Junta de Cultura Vasca y la redacción de un Catálogo Monumental para Bizkaia (1717-1936), Ars Bilduma, 9, 2019, p. 137-153, https://www.ehu.eus/ojs/index. php/ars_bilduma/issue/view/1757 (consultado el 15/10/2019).

GARCÍA GAINZA, M. C. y OTROS: Catálogo Monumental de Navarra, 9 vols., Pamplona, Institución Príncipe de Viana, 1980-1997.

GARCÍA GAINZA, M. C.: "Catálogo monumental de Navarra”, Anuario de Historia de la Iglesia, 8, 1999, pp. 371-374.

GARCÍA GAINZA, M. C.: "Inventarios y catálogos. Un siglo en la documentación y el conocimiento del Patrimonio Cultural (1907-2007)", en GONZÁLEZ GOMEZ, J. M. y MEJÍAS ÁLVAREZ, M. J. (coords.): Estudios de Historia del Arte: centenario del Laboratorio de Arte (1907-2007). Vol. 1, Universidad de Sevilla, 2009, pp. 181-198.

GONZÁLEZ-VARAS, I.: Conservación de Bienes Culturales. Teoría, historia, principios y normas. $4^{\mathrm{a}}$ ed., Madrid, Cátedra, 2005.

HERNÁNDEZ NÚÑEZ, J. C.: "Reflexiones sobre el Catálogo Monumental de España”, $P H$. Boletín del Instituto Andaluz del Patrimonio Histórico, 15, 1996, pp. 162-166.

HIDALGO BRINQUIS, M. C.: "Interpretación material de los Catálogos Monumentales de España", en El Catálogo Monumental de España (1900-1961). Investigación, restauración y difusión. Madrid, Ministerio de Educación, 2012, pp. 75-106.

ISAC MARTÍNEZ DE CARVAJAL, A.: "La ponencia de D. Leopoldo Torres Balbás en el VIII Congreso Nacional de Arquitectos de 1919”, Cuadernos de arte de la Universidad de Granada, 20, 1989, pp. 195-212.

LÓPEZ-YARTO ELIZALDE, A.: El Catálogo Monumental de España (1900-1961). Madrid, CSIC, 2010

LÓPEZ-YARTO ELIZALDE, A. y OTROS: El Catálogo Monumental de España (19001961). Investigación, restauración y difusión. Madrid, Ministerio de Educación, 2012. 
LÓPEZ-YARTO ELIZALDE, A.: “Los autores del Catálogo Monumental de España”, en El Catálogo Monumental de España (1900-1961). Investigación, restauración y difusión. Madrid, Ministerio de Educación, 2012, pp. 37-48.

MADRAZO, P.: España, sus monumentos y artes. Su naturaleza e Historia. Navarra y Logroño. Vol. II, Barcelona, Editorial de Daniel Cortezo, 1886.

MARTÍNEZ CANO, J.: “Fotografías en el Catálogo Monumental de Cuenca”, en VILLENA ESPINOSA, R. y LÓPEZ TORÁN, J. M. (eds.): Fotografía y patrimonio cultural. V, VI y VII Encuentros en Castilla-La Mancha, Cuenca, Universidad de Castilla-La Mancha, 2018, pp. 431-442.

MONTESA, M. de: “El sepulcro de Don Leonel”, Príncipe de Viana, 19, 1945, pp. 148-149.

MORALES, A. J.: Patrimonio histórico-artístico. Madrid, Historia 16, 1996.

MUÑOZ COSME, A.: "Catálogos e inventarios del Patrimonio en España”, en LÓPEZ-YARTO ELIZALDE, A. y OTROS: El Catálogo Monumental de España (1900-1961). Investigación, restauración y difusión. Madrid, Ministerio de Cultura, 2012, pp. 15-36.

QUINTANILLA MARTÍNEZ, E.: La Comisión de monumentos históricos y artísticos de Navarra. Pamplona, Gobierno de Navarra, 1995.

SÁNCHEZ VIGIL, J. M., OLIVEIRA ZALDÚA, M. y LÉON-SOTELO Y AMAT, M. T. de: La colección fotográfica Laurent en el Museo Textil de la Universidad Complutense de Madrid. Tipos y trajes populares. Madrid, Universidad Complutense, 2009.

SAURET GUERRERO, T.: "Los catálogos monumentales. La puesta en valor de los Bienes Patrimoniales por el conocimiento y la información especializada”, $\mathrm{PH}$. Boletín del Instituto Andaluz del Patrimonio Histórico, 32, 2000, pp. 61-65.

URQUIJO Y GOITIA, J. R. de: Gobiernos y ministros españoles en la Edad Contemporánea. Madrid, CSIC, 2001. 